\title{
Subnational Disparities in EU Law Use: Exploring the GEOCOURT Dataset
}

\author{
Arthur Dyevre* and Nicolas Lampach ${ }^{\dagger}$
}

\begin{abstract}
We present a new dataset compiling the geographic coordinates of the entire universe of courts that have passed on cases to the European Court of Justice over the lifetime of the European Union. The GEOCOURT Dataset allows the exploration of spatial disparities and clustering effects across time, member states and tiers of courts. Exploration of our new dataset reveals that involvement in the preliminary ruling procedure tends to be concentrated in a relatively small subset of regions within member states, often the region hosting the country's capital. We also consider several regional attributes associated with Article 267 use, which point out avenues for future research. Controlling for country and region fixed effects, we show that peak courts, GDP, population and capital along with with indicators of economic well-being and integration in cross-border trade are positively associated with referral propensity.
\end{abstract}

Keywords: Judicial behaviour, European Court of Justice, Machine Learning JEL Classification: K10, K40, N34, C11, C26

\footnotetext{
* Corresponding author: KU Leuven Faculty of Law, Centre for Legal Theory and Empirical Jurisprudence, 45 Tiensestraat, Leuven, Belgium; E-mail: arthur.dyevre@law.kuleuven.be; Phone: +32 16325387

$\dagger$, KU Leuven Faculty of Law, Centre for Legal Theory and Empirical Jurisprudence; E-mail: nicolas. lampach@kuleuven. be
} 


\section{Introduction}

The emergence of a decentralized EU legal system operating on the basis of cooperation between EU courts and national courts arguably constitutes one of the most remarkable achievements of European integration. ${ }^{1}$ What forces drive legal integration and sustain cooperation among domestic and EU judges are questions that have spawned a large multidisciplinary literature (Weiler, 1991; Rasmussen, 2012; Davies and Rasmussen, 2012; Davies, 2012; Sweet and Brunell, 1998; Conant, 2002; Cohen and Vauchez, 2007; Vauchez, 2010; Fligstein and Stone Sweet, 2002; Garrett, 1995; Alter, 2001; Pitarakis and Tridimas, 2003). Yet, despite the vastness of this literature, our understanding of legal integration appears both fragile and fragmented. Several studies have attempted to identify the determinants of referral activity (Sweet and Brunell, 1998; Pitarakis and Tridimas, 2003; Wind et al., 2009; Hornuf and Voigt, 2015; Carrubba and Murrah, 2005; Fligstein and Stone Sweet, 2002; Vink et al., 2009; Lampach and Dyevre, 2019). These studies, though, present serious weaknesses. Those that consider at least the six founding member states rely on data aggregated at country level. For that reason, they cannot disentangle the separate effects of adjudication and litigation dynamics, although this is arguably essential to our understanding of legal integration. Research has been further hampered by the relative dearth or incompleteness of data on national judiciaries, law firms and litigiousness. As for the more qualitative studies that have attempted to disaggregate the data to look at patterns of EU law use within states, they have rarely considered more than two or three member states at a time (Kelemen, 2011; Alter, 2001; Conant, 2002; Kelemen and Pavone, 2016, 2018; Chalmers, 2000; Alter and Vargas, 2000; Cichowski, 2007). Though this strand of scholarship has been better able to track and document the behaviour of domestic judges and litigants, the nature of their research design implies that their findings cannot be generalized to the rest of the EU.

In this paper we present a new dataset that may help address some shortcomings of the empirical literature on legal integration. Building off from Kelemen and Pavone (2016) and Kelemen and Pavone (2018), our dataset compiles the geographic coordinates of the entire universe of courts that have submitted a request for a preliminary ruling to the European Court of Justice (ECJ) up to 2017. Our GEOCOURT Dataset allows the exploration of spatial disparities and clustering effects across time, member states, subnational territorial units and tiers of courts. We show how the data can be used to construct maps, to explore spatial patterns and to investigate factors associated with referral activity. Our cartography of referring courts reveals that involvement in the preliminary ruling procedure tends to be concentrated in a relatively small subset of regions, often the country's capital city. We also explore other attributes potentially associated with referral activity. Applying regularized regression, we show that peak courts, GDP, population, capital cities, employment, primary income, life expectancy and EU trademark registrations are positively associated with referral propensity. Our exploration of the data suggests that EU law use is more intense in economic, judicial and international trade hubs. We highlight the impact of these factors as a potentially

\footnotetext{
${ }^{1}$ In the present paper we define the "EU legal system" or the "EU judiciary" as the the court system formed by the European Court of Justice and national judiciaries.
} 
important future research avenue, which the GEOCOURT Dataset will make easier for researchers to investigate.

\section{Challenges of Legal Integration Research}

Theory suggests that the enforcement of EU law by domestic courts is influenced by a variety of factors relating both to judges and litigants. The EU court system is not structured around an appeal procedure. Instead, the mechanism put in place by the Treaties is a referral regime. The decision to submit a reference is left to judges rather than to litigants. Moreover, although Article 267 of the Treaty on the Functioning of the European Union stipulates that peak courts have a duty to request a preliminary ruling from the Court of Justice when EU law is material to the case, the Treaties do not provide for any mechanism to reverse the decision of a peak court failing to uphold its obligation to ask for a preliminary ruling. Under an appeal system, losing litigants have the strongest incentive to appeal precisely in those cases in which they expect the appellate court to hold a diverging position (Cameron and Kornhauser, 2006). ${ }^{2}$ In contrast, expected divergence works as a disincentive to refer cases under a referral regime. In other words, a referral mechanism is not well designed to deal with agency loss arising from heterogeneity in the beliefs and preferences of judges across layers of the judicial system. In consequence, because preference heterogeneity is more likely to come in the way of inter-court cooperation under a referral than under an appeal regime, this may potentially cause large disparities in EU law use across judges and courts. Besides policy preferences, judicial decision making is also influenced by the resource-constraints that judges face in processing their caseload (Kornhauser, 1994; Kastellec, 2016). Workload and resources can show considerable variations across courts. These variations tend to follow the division of labour entailed by the hierarchical architecture of national judiciaries, with lower courts focusing on fact-finding and mass dispute resolution and top courts addressing broader law-finding and law creation issues. These factors provide additional reasons to expect divergence in the degree of zeal that domestic judges apply to the task of enforcing EU law.

Yet while judges and the institutional environment in which they operate are important, so too are litigants. It is reasonable to assume that domestic judges often apply EU law in response to the demands of the litigating parties rather than sua sponte. Yet the economic and commercial focus of EU legislation implies that some litigants have stronger incentives to make such a demand than others. Large corporations and powerful interest groups are more likely to be repeat players and to emerge as winners from litigation (Galanter, 1974; Songer et al., 1999). Scholars have argued that, for that reason, they are better positioned to benefit from EU law litigation (Conant, 2002, 80). Now, because the location of litigants fitting this description is unlikely to be uniform across the territorial jurisdiction of judicial bodies, we might expect them to amplify national and regional

\footnotetext{
${ }^{2}$ At the same time, the resulting litigant selection effect gives lower courts an incentive to anticipate reversal by conforming to the expected position of the appellate court (Cameron and Kornhauser, 2006, see).
} 
disparities in EU law application.

Empirically, the limitations of existing datasets have made untangling and assessing these hypotheses an arduous exercise. The quality and temporal coverage of judicial statistics differ considerably from member state to member state. Existing cross-country datasets, such as CEPEJ, suffer from multiple limitations, including restricted temporal coverage and high-level aggregation (court-tier rather than court). Limitations extend to the dependent variable - EU law use. There is no reliable, cross-country measure of EU law use. The Dec. Nat. Database compiles a large number of domestic cases dealing with EU law. But their selection is not motivated by replicable, systematic criteria. Even the focus of the database seems to have changed over time as the magnitude of the data collection effort started to strain the project's resources (Hübner, 2016). The CASELEX Database presents many of the same shortcomings (Mayoral, 2019). In consequence, EU judicial scholars have concentrated on Article 267 references as the most reliable gauge of EU law use. Domestic cases involving the application of EU law do not always give rise to a preliminary reference and the limited available evidence suggests that non-referred cases outnumber referred ones by one order of magnitude or more (Conant, 2002; Chalmers, 2000). Yet, insofar as references are more likely to arise where judges and litigants consider EU law arguments more frequently, referral rates remain the best available measure of the intensity of EU law use. Owing to the dearth of court-level data, though, scholars have opted to aggregate references at country level (Sweet and Brunell, 1998; Pitarakis and Tridimas, 2003; Carrubba and Murrah, 2005; Hornuf and Voigt, 2015; Wind et al., 2009; Vink et al., 2009; Lampach and Dyevre, 2019). While this choice appears understandable given the paucity of data on national judiciaries, it severely restricts the ability of researchers to draw inferences about the distinct influences of litigation and adjudication. All member states have peak courts and capital cities or economic hubs with greater concentrations of corporate headquarters or wealthy litigants. Unable to capture variations regarding these attributes, country-level analyses thus cannot tell us much about their impact on referral activity. In two ground-breaking papers, (Kelemen and Pavone, 2016) and (Kelemen and Pavone, 2018) showed that some of these limitations can be overcome if one shifts the analysis from the national to the subnational level. Kelemen and Pavone (2016) examine court participation in Article 267 proceedings across Italian regions and find litigiousness to be associated with greater referral activity in northern Italian regions but not in southern regions. Extending their approach to France and Germany, (Kelemen and Pavone, 2018) find referral activity to be more centralized in France than in Germany and Italy, a difference they link to variations in the institutional structure of the judiciary across the three countries. Their work further reports strong referral activity in regions with more specialized law firms as well as a higher incidence of free movement references in the port regions and manufacturing hubs of Germany and northern Italy (Kelemen and Pavone, 2018).

Our data collection effort builds off from the work of Tommasso Pavone and Daniel Kelemen. Our dataset expands the geographic scope of their mapping exercise to all EU member states and referring courts. This, in turn, allows us to explore a larger set of potential determinants of referral activity. 


\section{The GEOCOURT Dataset}

The GEOCOURT Dataset compiles the geographic coordinates of all the courts that submitted at least one preliminary reference over the period 1961-2017. Information on referring courts was collected, either manually or using computer scripts, from the EUR-Lex website. The geographic coordinates of the courts were then extracted from Google maps using web scraping methods. For each of the more than 8000 references issued by national courts, the following information was coded: member state of origin; case number; date on which the Court of Justice received the reference; date on which the Court of Justice issued its decision (whether order or ruling); name of the referring court; and position of the referring court in the domestic judicial hierarchy (first instance, intermediate, peak court). We were able to check some of that information against the dataset compiled by Sweet and Brunell (1998).

One limitation of the GEOCOURT Dataset is that it does not contain information on the courts that have never referred cases to the ECJ. ${ }^{3}$ This is more problematic for intermediate and first instance than for supreme and constitutional tribunals. There are only 70 peak courts in the entire European Union and nearly all of them have already made use of the preliminary ruling mechanism. ${ }^{4}$ But the proportion of intermediate and lower courts that have participated in the preliminary ruling system is much lower. The GEOCOURT Dataset, therefore, cannot be used to compare the courts that have not been involved in Article 267 proceedings. However, it can be used to investigate the behaviour of courts that have been socialized into the preliminary ruling system or, as we show below, to explore regional dynamics.

\subsection{Cartography}

Depicted in Figure A2 are cumulated referrals across the EU territory for the period 1961-2017.

\footnotetext{
${ }^{3}$ However, we hope to adress this limitation in future extensions.

${ }^{4} \mathrm{~A}$ peak court is defined as either a supreme court or a constitutional court.
} 


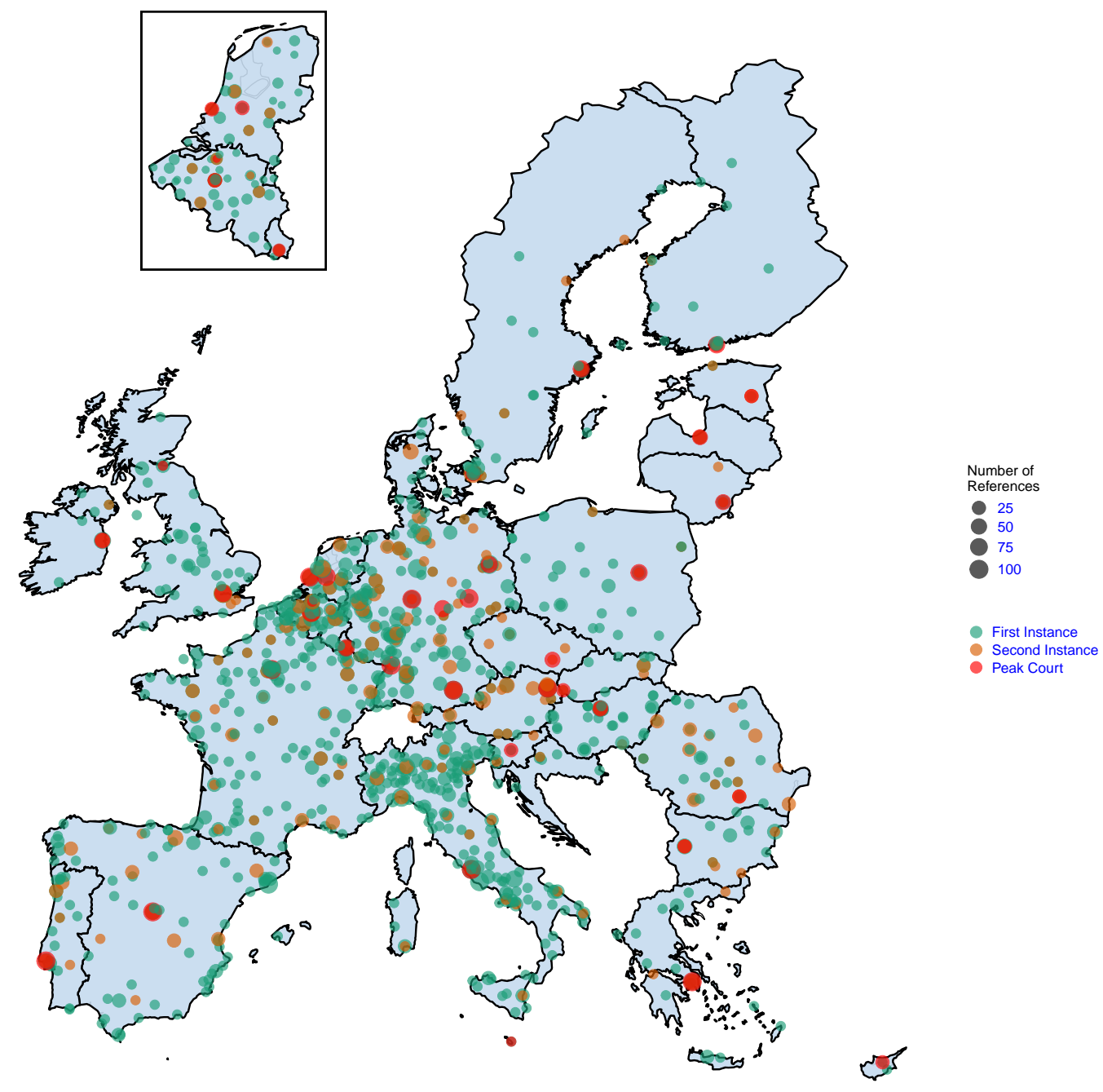

Figure 1: Referral activity across EU territory, 1961-2017.

Note: Colour denotes court level in domestic judicial hierarchy. Dot size represents number of referrals. 


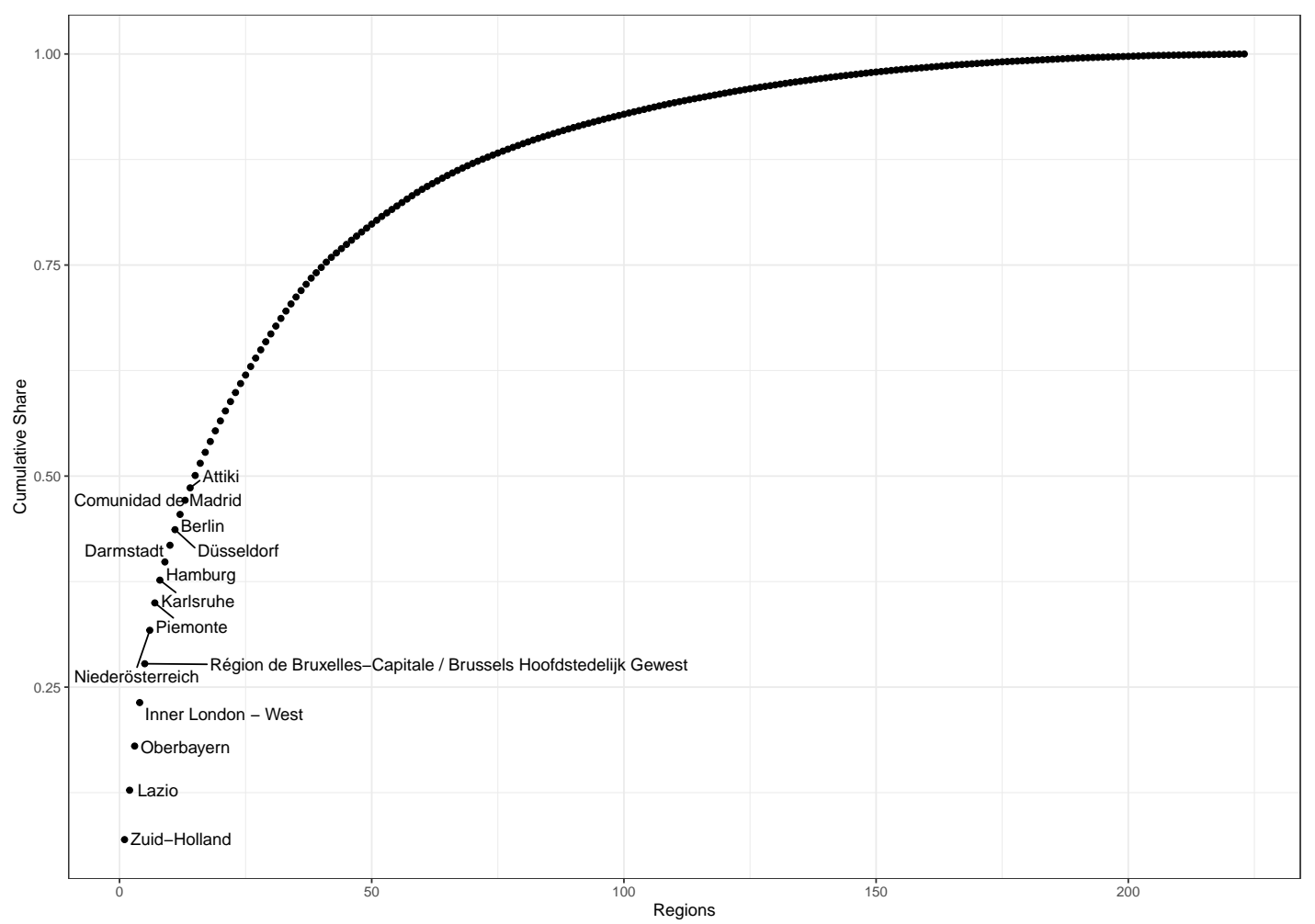

Figure 2: Cumulative share of references from most to least-referring NUTS-2 regions, 1961-2017.

Our maps reveal interesting patterns. One is the importance of peak courts. Some scholars have described lower courts as the engine of legal integration (Alter, 1998). Yet, through time peak courts have become larger purveyors of preliminary references, as evidenced by the arc of large reddish dots going from Dublin (where the Irish Supreme Court is located) to Helsinki (seat of the two Finnish supreme courts). Top courts still account for the largest dots in the three countries where none is located in the capital, namely the Czech Republic, where peak courts are all located in Brno, Estonia, where Tartu (not Tallinn) is the seat of the Supreme Court, and Germany, where peak courts are located in five different cities. ${ }^{5}$ Kelemen and Pavone (2018) had already detected a shift towards greater involvement of higher courts in France, Italy and Germany. This trend was confirmed by Dyevre et al. (2019) who compared referral rates across lower and higher courts in all member states. The high referral propensity of supreme courts appears to reflect the allocation of resources and legal tasks within domestic judiciaries (Dyevre et al., 2019).

\footnotetext{
${ }^{5}$ The Bundesverwaltungsgericht initially had its seat in West Berlin, but the Court was relocated to Leipzig in 1997, three years after the capital of reunified Germany was transferred from Bonn to Berlin.
} 


\subsection{Variations at NUTS-2 Level}

To facilitate the exploration and analysis of regional variations in referral activity, the GEOCOURT Dataset assigns the referring courts to their respective the NUTS-2 territorial units. ${ }^{6}$ Our choice of NUTS-2 over NUTS-3 or NUTS-1 is motivated by the greater availability of covariates for NUTS-2 as well as by the difficulty of matching geographic coordinates - which we found to be considerably more difficult for the smaller NUTS-3 units. Another advantage of aggregating the data at this level is that we can safely assume that there are judicial bodies in all our territorial units ${ }^{7}-$ an assumption that would be more precarious with a NUTS-3 aggregation. NUTS-2 regions correspond to Spanish "Comunidades", French "régions", German "Regierungsbezirken" or Belgian "provinces". Adding Croatia, which joined the EU in 2013, this adds up to 273 regions. ${ }^{8}$

Striking when looking at the data aggregated at regional level is the relatively high level of concentration of referral activity. As illustrated by Figure 2, less than 20 regions account for more than 50 per cent of referral activity. In most member states, participation in the preliminary ruling procedure tends to be concentrated in one or two regions. The most referring region is often the seat of the country's capital, as is the case for Austria (Niderösterreich), the UK (Inner London West), Italy (Lazio), Hungary (Közép-Magyarország), Belgium (Bruxelles Capitale), Poland (Mazowiecki), Bulgaria (Yugozapaden), Spain (Comunidad de Madrid), Finland (Helsinki-Uusimaa), Portugal (Area Metropolitana de Lisboa) and Greece (Attiki), Germany is an exception to this pattern in the sense that its most-referring regions (Oberbayern and Karlsruhe) do not host the country's capital. The Netherlands is a special - and somewhat misleading - case. Officially, Amsterdam, in the province of Northern Holland, is the country's capital. Yet the seat of the government, together with that of the two main Dutch supreme courts, is in The Hague, in the province of Southern Holland, which, on top of accounting for the largest share of Dutch references, exhibit the second-highest referral activity of all EU NUTS-2 regions. While Italy and Germany appear more decentralised with high referral rates outside the capital (a good example being the Italian region of Piemonte), most member states look in their majority more like France and its allegedly centralized judiciary (Kelemen and Pavone, 2018). Since peak courts have jurisdiction over the entire territory of a member state, one may feel inclined to attribute the high share of capital regions to their presence. Yet Figure A in the Supplementary Materials shows that many references originating in capital regions come from lower courts. In Austria, Belgium, Bulgaria, Denmark, Finland, France, Greece, Hungary, Ireland, Portugal, Sweden and the UK, non-peak courts located in the capital region account for a remarkably high share of references.

Overall, this cartography of Article 267 use suggests that referral activity tends to

\footnotetext{
6"NUTS", which stands for Classification of Territorial Units for Statistics (or "Nomenclature des unités territoriales statistiques" in French), is a geocode standard developed and used by EU institutions (See Table 3).

${ }^{7} \mathrm{~A}$ rough estimate from CEPEJ data puts the number of courts in the entire EU at approximately 8000 .

${ }^{8}$ Note that for Cyprus, Estonia, Latvia, Luxembourg and Malta, the entire country forms a single NUTS-2 region.
} 
cluster in regions that enjoy a particular status either as seat of the country's top courts or of its capital. Aside from the presence of a peak court or hosting the country's capital, though, there are many regional attributes that we might imagine could affect referral activity. We explore some of them in the next Section. 


\section{Regional Attributes Associated with Variations in Referral Activity}

To flag interesting avenues for future research, we consider a number of regional characteristics that could potentially be associated with variations in referral rates. We emphasise that our aim, here as in the previous section, is primarily exploratory. While we offer some speculations about what may explain the relations we find, we leave it to future research to establish whether they really amount to causal connections. In other words, just like visuals in the previous section, our exploratory data analysis serves to identify interesting patterns which have the potential to become causal hypotheses in future research.

\subsection{Regional Attributes}

As already mentioned, the GEOCOURT Dataset does not indicate how many courts there are in each region. Yet it does report which regions have a peak court and which do not. To the extent that peak courts account for a large share of referrals, this feature can be exploited to partial out what impact a peak court has on referral activity. On the other hand, if the focus of the research is on litigation, region fixed effects can serve to untangle the influence of litigation dynamics from unobserved variations in the number and type of (non-peak) courts.

Aside from the presence of peak courts and capital cities, our exploratory data analysis considers a range of demographic and economic variables from Eurostat. These include population, migration, GDP, primary income, agricultural production, business activity, employment, tourism, EU trade mark registrations and R\&D expenditures. Some of these variables have been discussed in the Article 267 literature (Sweet and Brunell, 1998; Pitarakis and Tridimas, 2003; Wind et al., 2009; Hornuf and Voigt, 2015; Carrubba and Murrah, 2005; Fligstein and Stone Sweet, 2002; Vink et al., 2009; Lampach and Dyevre, 2019; Kelemen and Pavone, 2016). Others are indicators that might plausibly be related to referral rates either because they may affect litigiousness or because they make EU law more relevant to regional activity. Indicators of economic prosperity and well-being have been linked to subnational variations in litigation rates (Eisenberg et al., 2012; Jacobi, 2009). Also because the construction of the internal market is central to EU rules and regulations, activities involving cross-border movements of goods, services, workers and tourists are especially likely to be subject to EU law (Conant, 2002; Sweet and Brunell, 1998) and, therefore, to give rise EU law litigation, The same line of reasoning motivates our inclusion of the presence of a large cargo port in the region, which Kelemen and Pavone (2018) put forward as a possible determinant of judicial participation in the preliminary ruling system. The complete list of regional variables together with their source, definition and operationalization, is reported in the Supplementary Materials (Table 2).

\subsection{Additional Covariates}

To partial out the effect of regional attributes we also include economic, political and legal covariates measured at the national level that have been discussed in the empirical 
literature, such as support for EU membership and the number of veto players (Sweet and Brunell, 1998; Pitarakis and Tridimas, 2003; Wind et al., 2009; Hornuf and Voigt, 2015; Carrubba and Murrah, 2005; Fligstein and Stone Sweet, 2002; Vink et al., 2009; Lampach and Dyevre, 2019). Since peak courts have nation-wide jurisdiction, countrylevel, time-varying factors, such as the number of legal disputes or the legal tradition, may affect their referral activity. Similarly, time-invariant factors like the legal tradition and the existence and scope of judicial review may influence the overall reception of EU law by domestic judges (Lampach and Dyevre, 2019; Hornuf and Voigt, 2015). For these reasons, we include indicators of litigiousness from Eurostat as well as various governance indicators from the World Bank. The complete list of covariates together with their source, definition and operationalization, is reported in the Supplementary Materials (Table 2).

As many of our indicators have missing values, we apply random forest (Breiman, 2001) to obtain complete cases (Tang and Ishwaran, 2017). Owing to limitations in data availability for many covariates, we restrict our exploratory analysis to the period 19982017.

\subsection{Methodology: Penalized Regression}

Our estimation strategy is motivated by the (quasi-)high-dimensional nature of our dataset as well as by the necessity to address collinearity. First, we want to estimate the regression coefficients for our regional attributes and additional coveriates while accounting for region, country and year fixed effects. This entails a regression model with more than 200 regressors. Second, as reported in the Supplementary Materials, some of our variables are highly correlated. This applies for economic (GDP, primary income, employment, trademark registrations) and governance (government efficiency, rule of law, voice, political stability) indicators, which have correlation coefficients above or close to 0.9 (see Figure A4). But the problem is even more acute for the indicators that vary little, or not at all, over time, such as the presence of a peak court or of a large cargo port in the region. Standard regression techniques are not well designed for this kind of estimation tasks. Multi-collinearity, in particular, results in biased coefficients or in convergence failure (as is the case with our data). Penalized regression is a suite of techniques developed to address such estimation problems (van Wieringen, 2015). The penalized regression method we use in this paper, ridge regression, addresses multi-collinearity by introducing a penalty parameter, $\lambda$, which allows coefficients that contribute little to out-of-sample model fit to get close to zero (Hoerl and Kennard, 1970; van Wieringen, 2015). One way to understand $\lambda$ is as putting a conservative prior on coefficients. ${ }^{9}$ This conservative prior requires that the data speaks loudly enough to produce coefficient estimates far from zero. Formally, $\lambda$ is a penalty on model complexity. Higher $\lambda$ values result in more parsimonious models that explain less variance but generalize better to new data, whereas lower

\footnotetext{
${ }^{9}$ Ridge regression seeks to minimize $\sum_{i=1}^{n}\left(y_{i}-\hat{y}_{i}\right)^{2}+\lambda \sum_{j}^{m} \beta_{j}^{2}$ where the expression on the left is the typical residual sum of squares measure in linear regression and the right term is the ridge penalty. Ridge regression is closely related to LASSO regression, which uses the absolute value of the vector norm $\lambda \sum_{j}^{m}\left|\beta_{j}\right|$ instead of $\lambda \sum_{j}^{m} \beta_{j}^{2}$. See van Wieringen (2015). We opt for the ridge approach rather than the LASSO variant because our concern is multi-collinearity not variable selection.
} 
$\lambda$ values result in more complex models that explain more variance but are more prone to overfitting. (When $\lambda=0$ the model is equivalent to a standard regression.) To find the $\lambda$ value that strikes the best balance between variance and bias, the prevailing practice is to use iterated, k-cross-validation (van Wieringen, 2015, 22).

Technicalities aside, ridge regression works quite like standard regression - whether OLS or count data variants. Ridge regression coefficients, in particular, can be interpreted in the same manner as standard regression coefficients. This and its ability to handle datasets with large number of covariates make ridge regression well-suited for the present exploratory task.

Our dependent variable - referral rates - can only take on non-negative integer values and includes many zeros. As it is best approximated by a negative binomial distribution, we employ the function for penalized negative binomial regression implemented in the mpath package for $\mathrm{R}$. To select the optimal $\lambda$, we apply 10-fold cross-validation with five iterations. We compute bootstrapped standard errors and confidence intervals by iterating our model selection procedure 1000 times. $^{10}$ To ensure that the same penalty is applied to all covariates, we normalise them prior to estimation so that all lie in the unit interval [0,1] (van Wieringen, 2015).

\subsection{Results}

Estimated coefficients along with 95 per cent confidence bounds from bootstrapped standard errors are reported in Table 1. Regional variables are reported in italic. Since the main contribution of the GEOCOURT Dataset is to enable the investigation of subnational patterns, we concentrate our attention on these variables. We only note that six country-level variables show a positive and significant association with Article 267 use: the existence of a specialised constitutional court (Constitutional Court), public support for European integration (EU Support), trade in goods with other member states (IntraEU Trade, Eurostat data), trade in both goods and services with EU member states as well as with the rest of the world (Trade in Goods and Services, OECD data), political stability ((Political Stability) and government efficiency (Government Efficiency). Meanwhile, seven are significantly but negatively associated with referral activity: first instance criminal cases (Lower Court Criminal), corruption (Corruption), the existence and scope of the domestic courts' power of judicial review (Judicial Review), regulatory quality (Regulatory Quality), accountability (Voice), respect for the rule of law (Rule of Law) and legal tradition (Common Law and Mixed Law).

Several regional attributes come out as positive and significant predictors of referral activity. Not surprisingly, being the seat of the country's capital (Capital) or the seat of a peak court (Peak Court) is associated with higher referral rates. So too is the number of residents (Population). As recent research has argued (Dyevre et al., 2019), supreme courts, especially at more advanced stages of integration, tend to benefit more, in terms of law-finding and law creation, from cooperating with the CJEU than is generally the case for lower courts. Although a capital city effect may reflect the presence of

\footnotetext{
${ }^{10}$ Note that because each bootstrapped iteration involves parameter tuning via cross-validation, our $\mathrm{R}$ implementation is computationally intensive.
} 
central political institutions and the sort of litigation they give rise to, business activity is another possible explanation. In addition to linking European integration to increased geographical clustering of business activity (Brülhart and Koenig, 2006), economic studies have linked economic integration with greater levels of concentration of service sector activity in capital cities (Melchior, 2012). Since EU law protects the free movement of services, service providers established in capital cities may constitute a pool of potential litigants with strong incentives to use EU law. ${ }^{11}$ The capital effect may be an interesting area of investigation for future research.

Also positively and significantly associated with referral activity are several indicators of economic prosperity and well-being: income before social transfers (Primary Income), regional gross domestic product (GDP), the number of persons employed (Employment), medical doctors per 100000 people (Health Care) and longevity (Life Expectancy). These indicators, which are themselves strongly correlated (see Figure A4 in Supplementary Materials), suggest a link between participation in the preliminary ruling system and economic prosperity. That the haves have greater incentives to litigate than the have-nots is a classic theoretical argument (Galanter, 1974; Songer et al., 1999). Empirical studies of US and Indian states have also documented a link between regional GDP and litigation rates (Eisenberg et al., 2012; Jacobi, 2009). This wealth effect may be even more pronounced in the case of EU law (see Conant, 2002, 80). The number of EU trademark registrations (EU Trade Mark) is another positive and significant predictor of Article 267 use. It strongly correlates with primary income, GDP, employment, medical doctors (Health Care) and R\&D. EU trademark registrations may capture a linkage between economic integration, trade and economic well-being. The EU's richer regions are more exposed to trans-border trade, which is also what, according to economic research, explains their prosperity in the first place (Henderson, 2000; Brülhart, 2011). The number of EU trade mark registrations may simply be a proxy for the number and size of firms involved in cross-border trade. Unlike national trademarks, EU trademarks provide protection in all member states. Yet, the application process is more expensive (albeit less so than for separate applications in all member states) and more cumbersome (an objection in any member state can defeat the entire application). The benefits of an EU trademarks outweigh its costs only when a business operates in more than four member states, making it a tool for multinationals. While the relationship between cross-border trade has received a lot of attention in the Article 267 literature (Sweet and Brunell, 1998; Wind et al., 2009; Kelemen and Pavone, 2016; Dyevre and Lampach, 2018; Pitarakis and Tridimas, 2003), our exploratory analysis illustrates how the GEOCOURT Dataset might help sharpen our understanding of the interplay of trade, wealth and EU law use. Interestingly, the coefficient for Cargo Port - operationalised as a port with 1 million annual cargo tonnage or more - is positive but non significant, which may be because it captures only trade in goods whereas EU trade mark registrations also capture cross-border trade in services. In any case, we see the interaction among trade, economic prosperity and EU law litigation as an important avenue for future research based on the GEOCOURT Dataset.

\footnotetext{
${ }^{11}$ In keeping with this explanation, a corpus dissimilarity analysis indicates that references originating from capital cities are significantly more likely to contain the words "services", "freedom" and "establishment" than references from other regions. See Figure A5.
} 
Migration is not significant, while Tourism exhibits a negative coefficient, which is only significant at the $p=0.1$ level. This supports, again, the centrality of trade and economic activity to EU law litigation. The EU's remit now expands to a broader set of policy areas. But consolidating and deepening the internal market remainsa central objective of EU laws and regulations and, therefore, of EU law litigation. This may be well be the reason why, unlike indicators associated with trade-related activity, indicators capturing flows of individuals are unable to explain much regional variation in referral rates. But we leave this question for future research.

In terms of significance and relative coefficient size, we believe that these results offer a robust baseline for future research. Not only does our approach rely on cross-validation to select the $\lambda$ penalty and on bootstrapped standard errors to compute confidence intervals, but it also includes country, region and year fixed effect to partial out the influence of country, region and cross-section-invariant unobserved factors. Hence researchers interested in furthering our understanding of legal integration in Europe should feel confident to use these results as a guide to decide what factors may point to promising hypotheses and what controls to include in their (more conventional and more parsimonious) regression models. 
Table 1: Negative binomial ridge regression with year, country and region fixed effects. (Regional variables are in italic.)

\begin{tabular}{|c|c|c|c|}
\hline & Estimate & Std.Err ${ }^{a}$ & $95 \% \mathrm{CI}^{a}$ \\
\hline Intercept & -73.045 & $10.478^{* * *}$ & {$[-93.581,-52.509]$} \\
\hline Capital & 0.136 & $0.055^{* *}$ & {$[0.028,0.243]$} \\
\hline Cargo Port & 0.024 & 0.029 & {$[-0.034,0.081]$} \\
\hline Peak Court & 0.191 & $0.048^{* * *}$ & {$[0.098,0.285]$} \\
\hline Membership & -0.007 & 0.036 & {$[-0.078,0.064]$} \\
\hline Constitutional Court & 0.099 & $0.030^{* * *}$ & {$[0.04,0.158]$} \\
\hline Monism & 0.034 & 0.024 & {$[-0.014,0.081]$} \\
\hline Judicial Review & -0.070 & $0.030^{* *}$ & {$[-0.128,-0.012]$} \\
\hline Judicial Power Index & -0.042 & 0.041 & {$[-0.122,0.037]$} \\
\hline Veto Player & 0.007 & 0.025 & {$[-0.042,0.056]$} \\
\hline EU Support & 0.057 & $0.024^{* *}$ & {$[0.01,0.104]$} \\
\hline Lower Court Cases (Other) & 0.023 & 0.030 & {$[-0.036,0.081]$} \\
\hline Lower Court Cases (Criminal) & -0.048 & $0.017^{* * *}$ & {$[-0.08,-0.015]$} \\
\hline Lower Court Cases (Civil and Commercial) & -0.005 & 0.034 & {$[-0.072,0.061]$} \\
\hline Lower Court Cases (Administrative) & 0.012 & 0.040 & {$[-0.067,0.09]$} \\
\hline Intra-EU Trade & 0.077 & $0.022^{* * *}$ & {$[0.033,0.121]$} \\
\hline Trade in Goods and Services & 0.053 & $0.030^{*}$ & {$[-0.006,0.112]$} \\
\hline Corruption & -0.053 & $0.016^{* * *}$ & {$[-0.085,-0.021]$} \\
\hline Regulatory Quality & -0.103 & $0.021^{* * *}$ & {$[-0.144,-0.062]$} \\
\hline Government Efficiency & 0.048 & $0.020^{* *}$ & {$[0.008,0.087]$} \\
\hline Political Stability & 0.065 & $0.022^{* * *}$ & {$[0.022,0.107]$} \\
\hline Voice & -0.112 & $0.022^{* * *}$ & {$[-0.155,-0.068]$} \\
\hline Rule of Law & -0.054 & $0.023^{* *}$ & {$[-0.098,-0.009]$} \\
\hline Business & -0.004 & 0.016 & {$[-0.035,0.027]$} \\
\hline Health Care & 0.124 & $0.022^{* * *}$ & {$[0.081,0.167]$} \\
\hline Agriculture & 0.002 & 0.027 & {$[-0.051,0.056]$} \\
\hline Unemployment & 0.012 & 0.025 & {$[-0.037,0.061]$} \\
\hline Employment & 0.102 & $0.021^{* * *}$ & {$[0.06,0.144]$} \\
\hline Tourism & -0.055 & $0.031^{*}$ & {$[-0.115,0.005]$} \\
\hline RED Expenditures & 0.011 & 0.025 & {$[-0.037,0.059]$} \\
\hline EU Trade Mark & 0.060 & $0.024^{* *}$ & {$[0.013,0.108]$} \\
\hline Primary Income & 0.041 & $0.016^{* *}$ & {$[0.009,0.072]$} \\
\hline$G D P$ & 0.067 & $0.023^{* * *}$ & {$[0.022,0.112]$} \\
\hline Migration & -0.009 & 0.025 & {$[-0.058,0.04]$} \\
\hline Life Expectancy & 0.043 & $0.021^{* *}$ & {$[0.001,0.084]$} \\
\hline Population & 0.109 & $0.019^{* * *}$ & {$[0.071,0.146]$} \\
\hline Common Law & -0.080 & $0.027^{* * *}$ & {$[-0.133,-0.027]$} \\
\hline Mixed Law & -0.022 & $0.01^{* *}$ & {$[-0.041,-0.003]$} \\
\hline Number of observations & \multicolumn{3}{|c|}{3881} \\
\hline RMSE & \multicolumn{3}{|c|}{7.023} \\
\hline
\end{tabular}




\section{Discussion and Conclusion}

Research on the EU court system has been hampered by data limitations. This has frequently led EU judicial scholars to restrict the scope of their empirical inquiry to crosscountry variations. In consequence, many research questions, notably those that required untangling adjudication and litigation dynamics, could not be properly investigated. The GEOCOURT Dataset does not address all the limitations of existing datasets. But, as we have tried to show, it opens up new possibilities to advance our understanding of legal integration. The GEOCOURT Dataset compiles information on all the courts that have requested a preliminary ruling over the period 1961-2017. The information includes the geographic coordinates of the courts, the position of the courts in the domestic judicial hierarchy, and the NUTS-2 region in which they are located. The GEOCOURT Dataset allows researchers to explore and investigate six decades of formal judicial cooperation between EU and national courts and to map referral activity across space, time and layers of courts. Visualizing the spatial distribution of referring courts can reveal interesting patterns and suggest new research questions. Illustrating this point, our cartography reveals significant spatial disparities. Regions which host the country's capital city or a peak court tend to refer substantively more than legally or politically more peripheral regions. The forty most-referring NUTS-2 regions account for 75 per cent of all references, whereas the 100 least-referring account for less than 10 per cent. Furthermore, examining 17 regional variables in a ridge regression setup, we found legal (peak court) and political (capital city) attributes as well as indicators relating to economic prosperity and trade to be strongly and positively associated with referral activity, Indicators capturing crossborder flows of private individuals (tourism, migration), by contrast, seem to offer less potential to explain spatial variations in referral activity. One narrative emerging from the analysis of the regional attributes is that referral dynamics are largely driven by top court judges and rich corporate litigants engaged in cross-border trade. Richer regions are more integrated in international trade, making EU law - which is still structured around the internal market objective - more salient to litgation and adjudication.

Our principal goal in this paper is exploratory and the interpretation of our findings is somewhat speculative, although, we believe, plausible. We do not claim to have identified causal relations. We leave causal identification for future research. But we hope to have demonstrated the value and potential of the GEOCOURT Dataset, which we are happy to make freely available to the research community. ${ }^{12}$

\section{Replication materials}

Supporting data and materials for this article can be accessed on the Taylor Francis website, doi:

\section{Word count: 7056}

\footnotetext{
${ }^{12}$ The GEOCOURT Dataset (together with NUTS-2 codes for regional aggregation) used in this paper can be downloaded from the portal of the EUTHORITY Project: www.euthority.eu
} 


\section{References}

Alter, K. J. (1998). Explaining National Courts Acceptance of European Court Jurisprudence: A Critical Evaluation of Theories of Legal Integration. In A.-M. Slaughter, A. Stone Sweet, and J. Weiler (Eds.), The European Court and National Courts - Doctrine and Jurisprudence, pp. 232.

Alter, K. J. (2001). Establishing the supremacy of European law: The making of an international rule of law in Europe. Oxford University Press Oxford.

Alter, K. J. and J. Vargas (2000). Explaining variation in the use of european litigation strategies: European community law and british gender equality policy. Comparative Political Studies 33(4), 452-482.

Breiman, L. (2001). Random forests. Machine learning 45(1), 5-32.

Brülhart, M. (2011). The spatial effects of trade openness: a survey. Review of World Economics 147(1), 59-83.

Brülhart, M. and P. Koenig (2006). New economic geography meets comecon. Economics of Transition 14(2), 245-267.

Cameron, C. M. and L. A. Kornhauser (2006). Appeals mechanisms, litigant selection, and the structure of judicial hierarchies. Institutional Games and the US Supreme Court, 173-204.

Carrubba, C. and L. Murrah (2005). Legal integration and use of the preliminary ruling process in the european union. International Organization 59, 399-418.

Chalmers, D. (2000). The positioning of eu judicial politics within the united kingdom. West European Politics 23(4), 169-210.

Cichowski, R. (2007). The European Court and Civil Society: Litigation, Mobilization and Governance. Cambridge University Press.

Cohen, A. and A. Vauchez (2007). Introduction: law, lawyers, and transnational politics in the production of europe. Law \& Social Inquiry 32(1), 75-82.

Conant, L. J. (2002). Justice Contained: Law and Politics in the European Union. Cornell University Press.

Davies, B. (2012). Resisting the European Court of Justice. Cambridge: Cambridge University Press.

Davies, B. and M. Rasmussen (2012, August). Towards a New History of European Law. Contemporary European History 21 (Special Issue 03), 305-318. 
Dyevre, A., M. Glavina, and A. Atanasova (2019). Who refers most? institutional incentives and judicial participation in the preliminary ruling system. Journal of European Public Policy, 1-19.

Dyevre, A. and N. Lampach (2018). The origins of regional integration: Untangling the effect of trade on judicial cooperation. International Review of Law and Economics.

Eisenberg, T., S. Kalantry, and N. Robinson (2012). Litigation as a measure of well-being. DePaul L. Rev. 62, 247.

Elkins, Z., T. Ginsburg, and J. Melton (2014). Comparative constitutions project. characteristics of national comparative. version 2 .

Fligstein, N. and A. Stone Sweet (2002). Constructing politics and markets: An institutionalist account of european integration. American Journal of Sociology 107(5), $1206-1243$.

Galanter, M. (1974). Why the" haves" come out ahead: Speculations on the limits of legal change. Law $\&$ society review 9(1), 95-160.

Garrett, G. (1995). The politics of legal integration in the European Union. International Organization 49, 171-171.

Henderson, J. V. (2000). The effects of urban concentration on economic growth. Technical report, National bureau of economic research.

Hoerl, A. E. and R. W. Kennard (1970). Ridge regression: Biased estimation for nonorthogonal problems. Technometrics 12(1), 55-67.

Hornuf, L. and S. Voigt (2015). Analyzing preliminary references as the powerbase of the european court of justice. European Journal of Law and Economics 39(2), 287-311.

Hübner, D. C. (2016). The 'national decisions' database (dec. nat): Introducing a database on national courts' interactions with european law. European Union Politics 17(2), $324-339$.

Jacobi, T. (2009, January). The Role of Politics and Economics in Explaining Variation in Litigation Rates in the U.S. States. The Journal of Legal Studies 38(1), 205-233.

Kastellec, J. (2016). The judicial hierarchy: A review essay.

Keefer, P. (2012). Database of political institutions: Changes and variable definitions. The World Bank: Development Research Group.

Kelemen, D. and T. Pavone (2016). Mapping european law. Journal of European Public Policy 23(8), 1118-1138.

Kelemen, D. and T. Pavone (2018). The political geography of european legal integration: Visualizing institutional change in the european union. World Politics 70(3). 
Kelemen, R. D. (2011). Eurolegalism: the transformation of law and regulation in the European Union. Harvard University Press.

Kornhauser, L. A. (1994). Adjudication by a resource-constrained team: Hierarchy and precedent in a judicial system. S. Cal. L. Rev. 68, 1605.

Lampach, N. and A. Dyevre (2019). Choosing for europe: judicial incentives and legal integration in the european union. European Journal of Law and Economics, 1-22.

Mayoral, J. A. (2019). Judicial empowerment expanded: Political determinants of national courts' cooperation with the cjeu. European Law Journal 25 (4), 374-393.

Melchior, A. (2012). East-west integration: A geographical economics approach. In EU Eastern Neighborhood, pp. 23-44. Springer.

Pitarakis, J. and G. Tridimas (2003). Joint dynamics of legal and economic integration in the european union. European Journal of Law and Economics 16, 357-368.

Rasmussen, M. (2012). Establishing a Constitutional Practice of European Law: The History of the Legal Service of the European Executive, 1952-65. Contemporary European History 21 (Special Issue 03), 375-397.

Songer, D. R., S. B. Haire, and R. S. Sheehan (1999). Do the" haves" come out ahead over time? applying galanter's framework to decisions of the us courts of appeals, 1925-1988. Law \& Society Review $33(4), 811$.

Sweet, A. S. and T. L. Brunell (1998). Constructing a supranational constitution: Dispute resolution and governance in the european community. American Political Science Review 92(1), 63-81.

Tang, F. and H. Ishwaran (2017). Random forest missing data algorithms. Statistical Analysis and Data Mining: The ASA Data Science Journal 10(6), 363-377.

van Wieringen, W. N. (2015). Lecture notes on ridge regression. arXiv preprint arXiv:1509.09169.

Vauchez, A. (2010). The transnational politics of judicialization. van gend en loos and the making of eu polity. European Law Journal 16(1), 1-28.

Vink, M., M. Claes, and C. Arnold (2009). Explaining the use of preliminary references by domestic courts in eu member states: A mixed-method comparative analysis. Conference paper Judicial Politics in the EU and Beyond 11th Biennial Conference of the European Union Studies Association.

Weiler, J. H. H. (1991). The Transformation of Europe. Yale L.J., 2403-2483.

Wind, M., D. S. Martinsen, and G. P. Rotger (2009). The uneven legal push for europe questioning variation when national courts go to europe. European Union Politics 10(1), $63-88$. 


\section{Supplementary Materials}

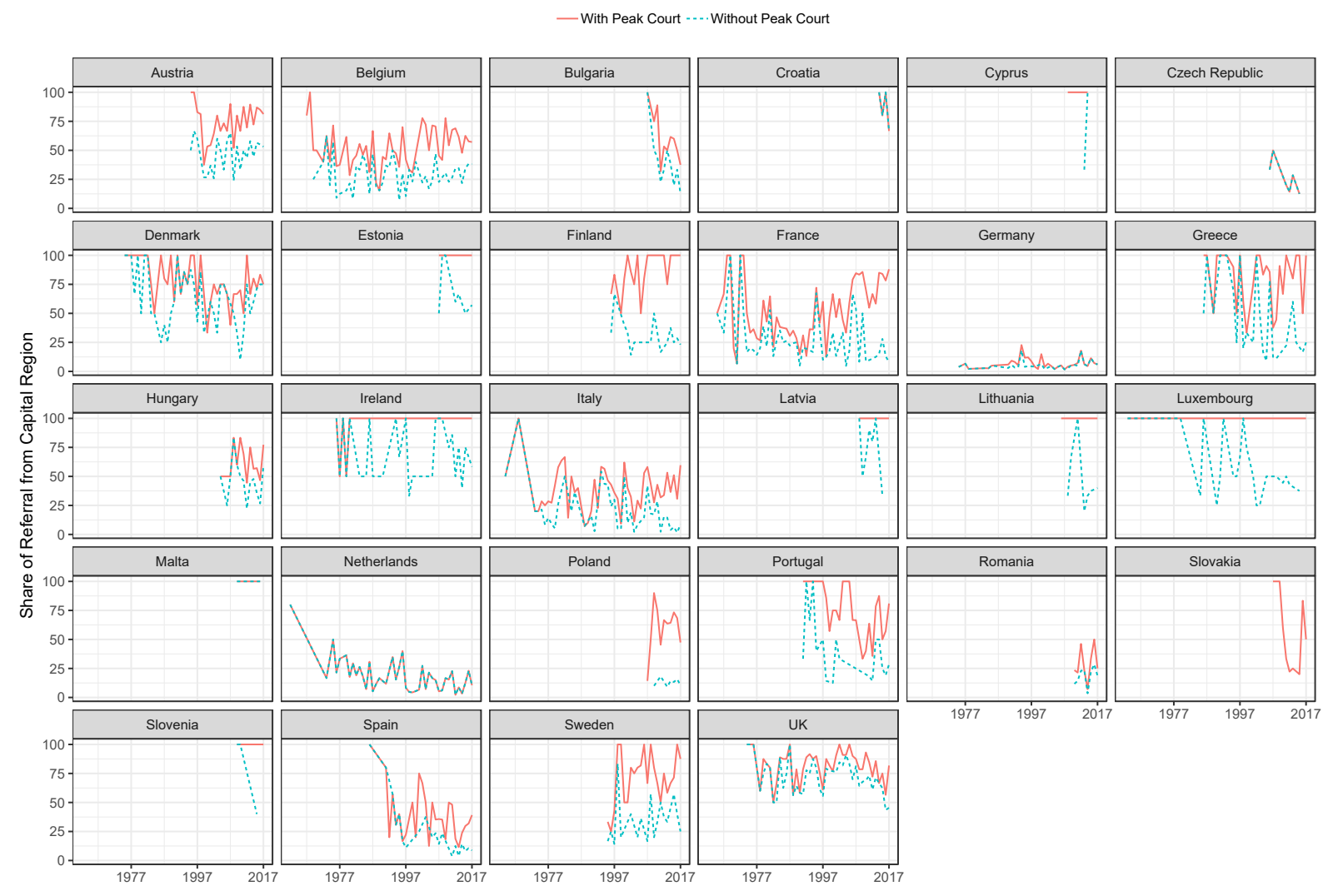

Figure A1: Share of references coming from courts in the capital region (NUTS-2), 19612017. 


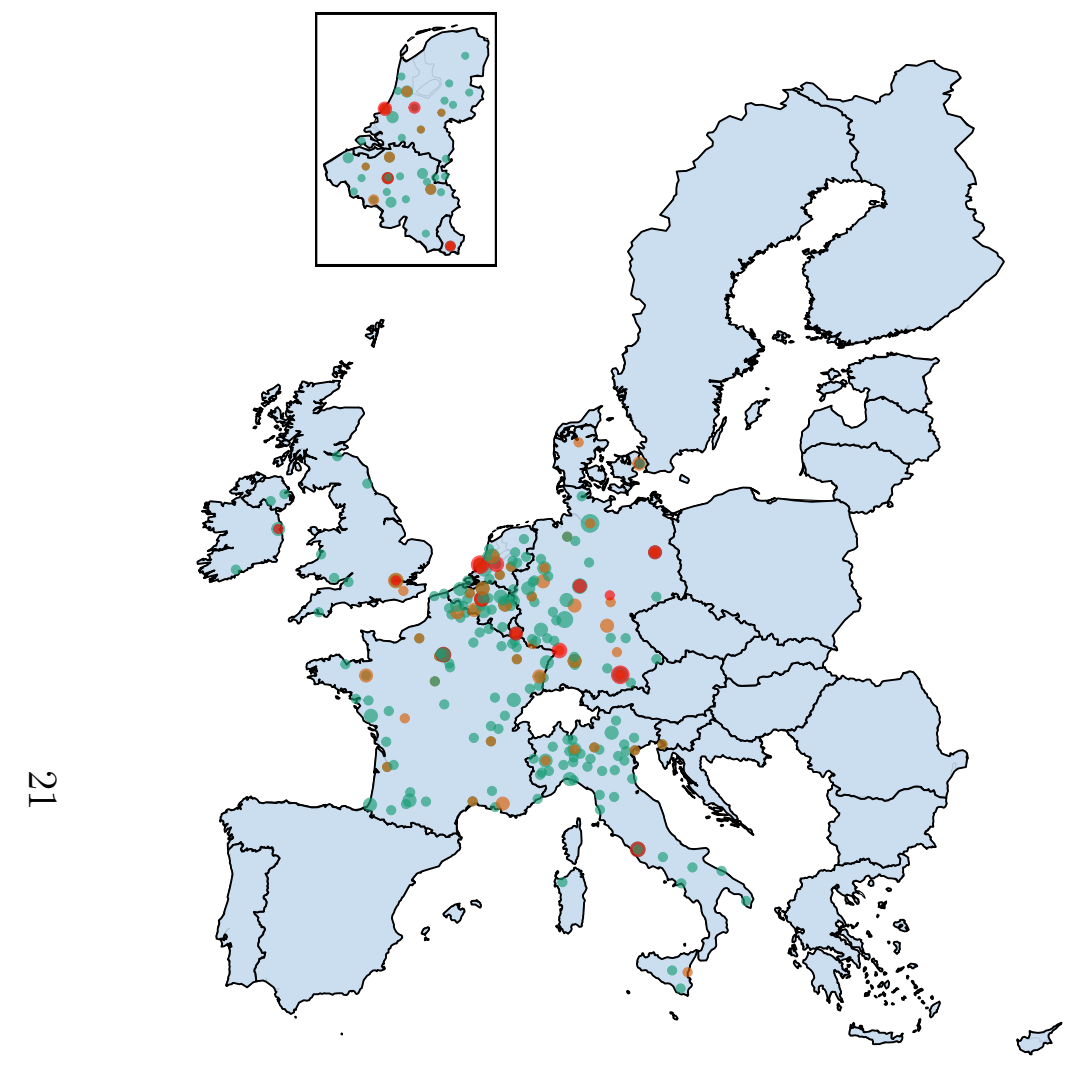

(a) $1961-1985$

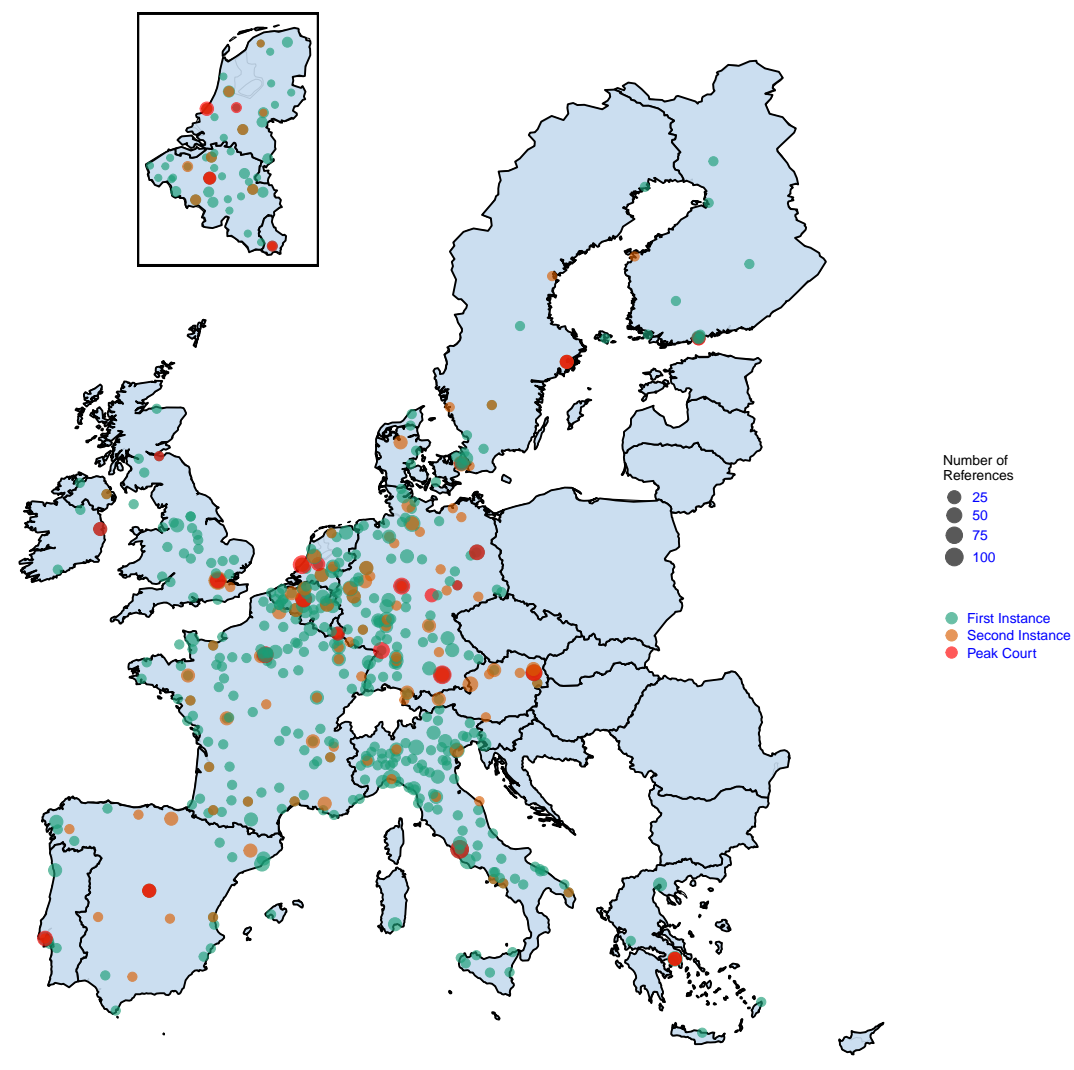

(b) $1986-2003$

Figure A2: Referral activity across EU territory.

Note. Colour denotes court level in domestic judicial hierarchy. Dot size represents number of referrals. Panel (a) plots referral activity in EU-10 (Belgium, Denmark, France, Germany, Greece, Italy, Ireland, Netherlands, Luxembourg and UK). Panel (b) plots referral activity in EU-15 (Austria, Finland and Sweden joined in 2004, Spain and Portugal in 1986). 


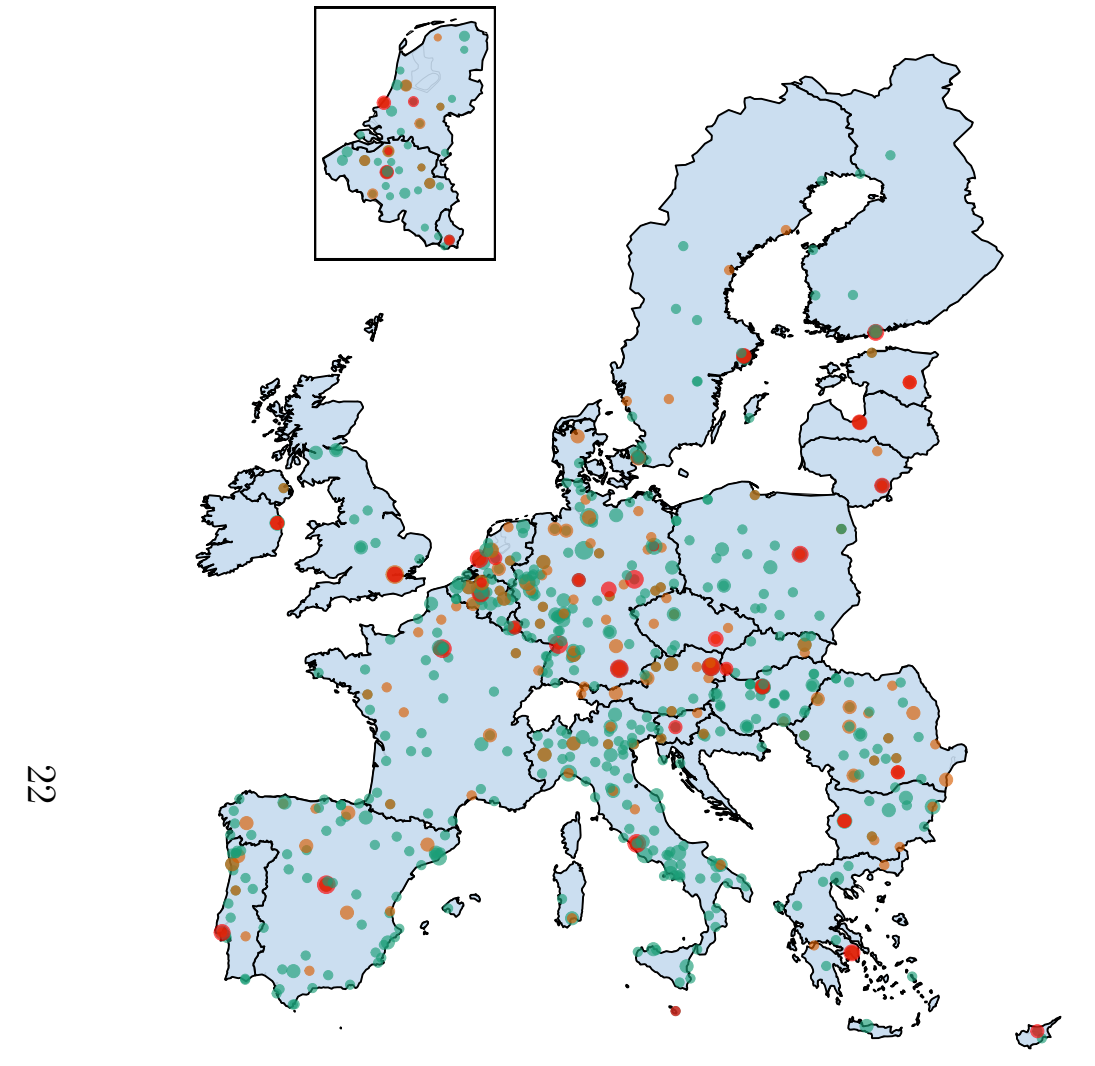

(c) 2004-2017

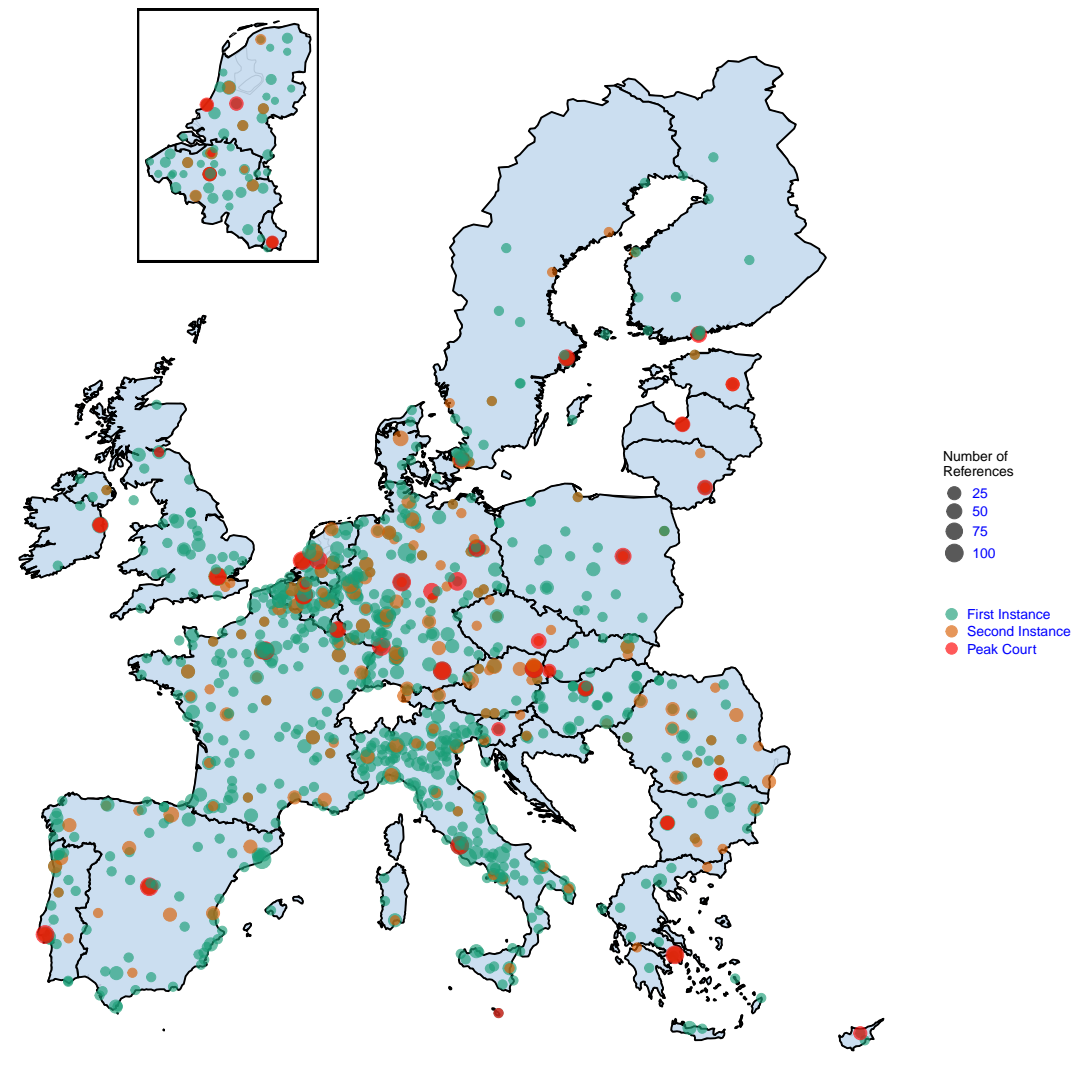

(d) $1961-2017$

Figure A2: Referral activity across EU territory.

Note. Panel (c) plots referral activity for EU-28 (Cyprus Czech Republic, Estonia, Hungary, Latvia, Lithuania, Malta, Poland, Slovakia and Slovenia joined in 2004, Bulgaria and Romania in 2007 and Croatia in 2013)). 


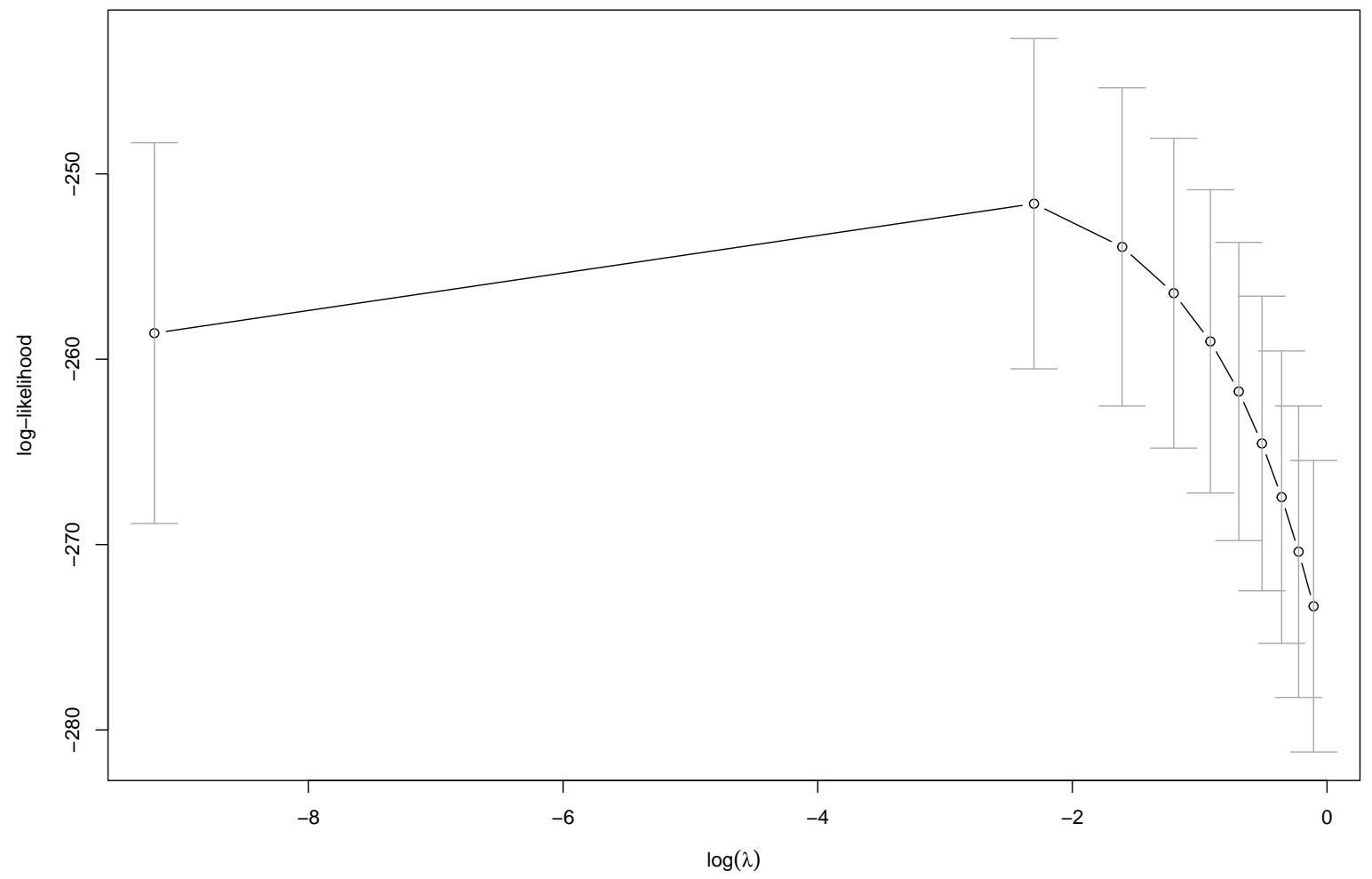

Figure A3: Tuning plot penalty term $\lambda$. 


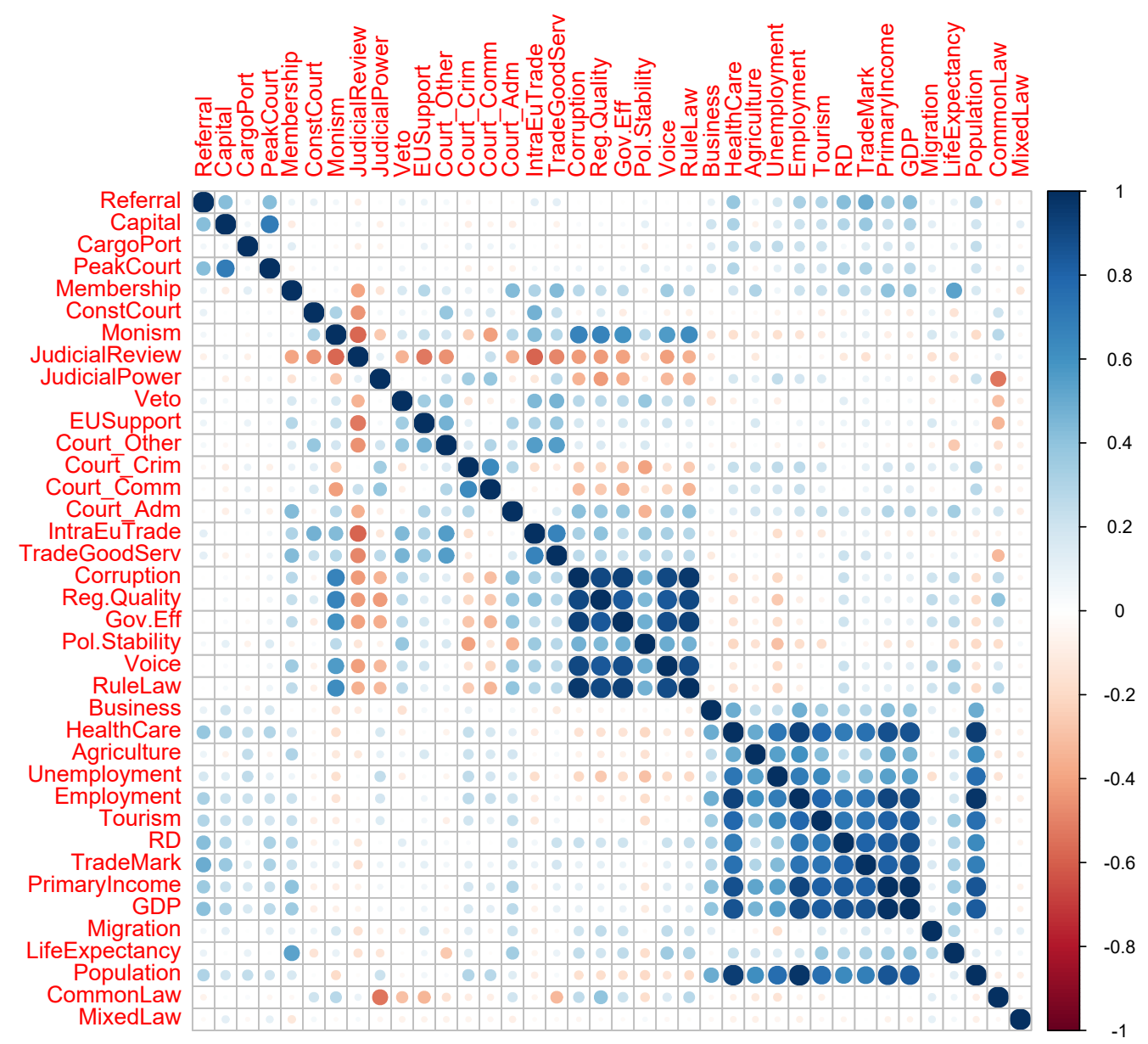

Figure A4: Correlation among covariates 
Figure A5 shows that words like "services", "freedom", "establishment", "telecommunications" and "copyright" occur at a higher rate in cases referred by courts located in capitals.

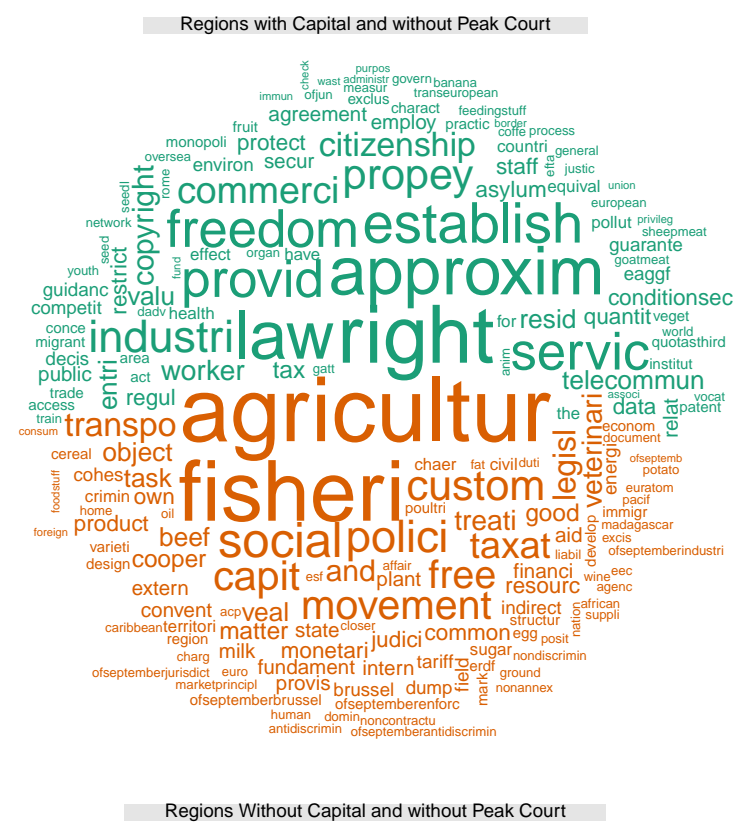

Figure A5: Comparison of most dissimilar words in cases originated in capital regions and cases originated in other EU regions. Cases referred by peak courts are excluded. Word size denotes deviation from expected occurrence. 
Table 2: List of variables

\begin{tabular}{|c|c|c|c|c|}
\hline Variable name & Explanation & Type of data & Unit & Source \\
\hline Referral $_{i, j, t}$ (Dependent variable) & $\begin{array}{l}\text { number of referrals submitted by referent court located in NUTS2 level } i \text { of } \\
\text { country } j \text { at time } t\end{array}$ & discrete & & GEOCOURT \\
\hline \multicolumn{5}{|c|}{ Regional level data } \\
\hline Agriculture $i, j, t$ & production value at basic prices by NUTS2 level $i$ and country $j$ at time $t$ & continuous & million Euro & Eurostat \\
\hline Business $_{i, j, t}$ & $\begin{array}{l}\text { number of active local units operating in service and infomation industry by } \\
\text { NUTS2 level } i \text { and country } j \text { at time } t\end{array}$ & continuous & number & Eurostat \\
\hline Capital $_{i, j}$ & $\begin{array}{l}\text { dummy variable taken the value } 1 \text { if the referent court is in the capital of } \\
\text { country } j \text { located in the NUTS2 region } i \text { and } 0 \text { otherwise }\end{array}$ & categorical & & NA \\
\hline Cargo Port $_{i, j, t}$ & $\begin{array}{l}\text { dummy variable taken the value } 1 \text { if the NUTS } 2 \text { region } i \text { in country } j \text { at time } \\
t \text { has a large cargo port ( port with } 1 \text { million annual cargo tonnage or more) } \\
\text { and } 0 \text { otherwise }\end{array}$ & categorical & & Eurostat \\
\hline Employment $_{i, j, t}$ & number of employed persons by NUTS2 level $i$ and country $j$ at time $t$ & continuous & Thousand & Eurostat \\
\hline $\mathrm{GDP}_{i, j, t}$ & $\begin{array}{l}\text { gross domestic product at current market prices by NUTS2 level } i \text { and country } \\
j \text { at time } t\end{array}$ & continuous & million Euro & Eurostat \\
\hline Health Care ${ }_{i, j, t}$ & number of medical doctors by NUTS2 level $i$ and country $j$ at time $t$ & continuous & number & Eurostat \\
\hline Life Expectancy ${ }_{i, j, t}$ & Life expectancy by NUTS2 level $i$ and country $j$ at time $t$ & continuous & year & Eurostat \\
\hline Migration $_{i, j, t}$ & net migration by NUTS2 level $i$ and country $j$ at time $t$ & continuous & number & Eurostat \\
\hline Nuts $\mathrm{ID}_{i, j}$ & NUTS2 level $i$ and country $j$ & categorical & & Eurostat \\
\hline Peak Court $_{i, j}$ & $\begin{array}{l}\text { dummy variable taken the value } 1 \text { if a top court is in the NUTS2 region } i \text { in } \\
\text { country } j \text { and } 0 \text { otherwise }\end{array}$ & categorical & & NA \\
\hline Population $_{i, j, t}$ & population on 1 January by NUTS2 level $i$ and country $j$ at time $t$ & continuous & number & Eurostat \\
\hline Primary Income $_{i, j, t}$ & $\begin{array}{l}\text { allocation of primary income account of households by NUTS2 level } i \text { and } \\
\text { country } j \text { at time } t\end{array}$ & continuous & million euro & Eurostat \\
\hline R\&D Expenditures $i_{i, j, t}$ & $\begin{array}{l}\text { total expenditures in research and development by NUTS2 level } i \text { and country } \\
j \text { at time } t\end{array}$ & continuous & million euro & Eurostat \\
\hline Tourism $_{i, j, t}$ & $\begin{array}{l}\text { arrivals at tourist accommodation establishments by NUTS2 level } i \text { and coun- } \\
\text { try } j \text { at time } t\end{array}$ & continuous & number & Eurostat \\
\hline Trademark $_{i, j, t}$ & $\begin{array}{l}\text { European Union Trade mark (EUTM) by NUTS2 level } i \text { and country } j \text { at time } \\
t\end{array}$ & continuous & number & Eurostat \\
\hline Unemployment $_{i, j, t}$ & number of unemployed persons by NUTS2 level $i$ and country $j$ at time $t$ & continuous & Thousand & Eurostat \\
\hline \multicolumn{5}{|c|}{ Country level data } \\
\hline Constitutional Court $_{j, t}$ & $\begin{array}{l}\text { dummy variable which takes the value one if member state has adopted Kelse- } \\
\text { nian (i.e. centralized) model of constitutional review and zero otherwise }\end{array}$ & categorical & & $\begin{array}{l}\text { Comparative Consti- } \\
\text { tution Project Elkins } \\
\text { et al. }(2014)\end{array}$ \\
\hline Common Law Countries $_{j}$ & $\begin{array}{l}\text { dummy variable which takes the value one if member state is UK or Ireland } \\
\text { and zero otherwise }\end{array}$ & categorical & & NA \\
\hline Corruption $_{j, t}$ & corruption by country $j$ at time $t$ & continuous & score & World Bank \\
\hline EU Support & $\begin{array}{l}\text { net percentage difference between respondents saying that EU membership is } \\
\text { a good thing and saying that EU membership is a bad thing }\end{array}$ & continuous & percentage & Eurobarometer \\
\hline Judicial Review $_{j}$ & $\begin{array}{l}\text { The review of constitutionality per country } j \text { is measured through an interac- } \\
\text { tion term; The term is composed by the the stage of the legislative process at } \\
\text { which a bill can be reviewed for constitutionality (chalstag) and the existence } \\
\text { of judicial review }\end{array}$ & categorical & & $\begin{array}{l}\text { Comparative Consti- } \\
\text { tution Project Elkins } \\
\text { et al. (2014) }\end{array}$ \\
\hline Judicial Power $_{j}$ & $\begin{array}{l}\text { Based on Elkins et al. (2014) dataset, we create an original scale from } 0 \text { to } 7 \\
\text { indicating the judicial power of country } j \text {. The judicial power index comprises } \\
13 \text { indicators and is the sum of: (1) review by any courts, (2) review by } \\
\text { constitutional courts, ( } 3 \text { ) review by supreme court, (4) review by chamber of } \\
\text { supreme court, (5) challenge by executive, ( } 6 \text { ) challenge by legislature, ( } 7 \text { ) } \\
\text { challenge by public, ( } 8 \text { ) challenge by ordinary courts, (9) challange by other, } \\
\text { (10) effect is to void law minus (i) effect limited to individual case, (ii) effect } \\
\text { is to return law to legislation, (iii) effect is other }\end{array}$ & continuous & score & $\begin{array}{l}\text { Comparative Consti- } \\
\text { tution Project Elkins } \\
\text { et al. (2014) }\end{array}$ \\
\hline Intra-EU Trade ${ }_{j, t}$ & Annual volume of intra EU-trade (export plus import) by country $j$ at time $t$ & Continuous & Mrd. Euro & $\begin{array}{l}\text { Ameco macro- } \\
\text { economic database }\end{array}$ \\
\hline Lower Court Cases $(\text { Other })_{j, t}$ & number of other cases brought before to lower courts by country $j$ at time $t$ & continuous & number & Eurostat \\
\hline Lower Court Cases (Criminal $)_{j, t}$ & $\begin{array}{l}\text { number of criminal cases brought before to lower courts by country } j \text { at time } \\
t\end{array}$ & continuous & number & Eurostat \\
\hline Lower Court Cases (Civil and Commercial) $)_{j, t}$ & $\begin{array}{l}\text { number of civl/commercial cases brought before to lower courts by country } j \\
\text { at time } t\end{array}$ & continuous & number & Eurostat \\
\hline Lower Court Cases (Administrative) $)_{j, t}$ & $\begin{array}{l}\text { number of administrative cases brought before to lower courts by country } j \text { at } \\
\text { time } t\end{array}$ & continuous & number & Eurostat \\
\hline Membership $_{j, t}$ & number of years elapsed since accession to the European Union & continuous & & NA \\
\hline Mixed Law Countries $_{j}$ & $\begin{array}{l}\text { dummy variable which takes the value one if member state is Malta or Cyprus } \\
\text { and zero otherwise }\end{array}$ & categorical & & $\mathrm{NA}$ \\
\hline Monism $_{j, t}$ & $\begin{array}{l}\text { dummy variable taking the value one if treaties are granted superiority over } \\
\text { domestic legislation to ordinary legislation in the country } i \text { and zero otherwise }\end{array}$ & categorical & & $\begin{array}{l}\text { Comparative Consti- } \\
\text { tution Project Elkins } \\
\text { et al. (2014) }\end{array}$ \\
\hline Political Stability $j_{j, t}$ & political stability and absence of violence by country $j$ at time $t$ & continuous & score & World Bank \\
\hline Regulatory Quality $j, t$ & regulatory quality by country $j$ at time $t$ & continuous & score & World Bank \\
\hline Rule of Law $\mathrm{Lw}_{j, t}$ & rule of law by country $j$ at time $t$ & continuous & score & World Bank \\
\hline Trade of goods and services ${ }_{j, t}$ & net trade of goods and services at current prices (in $\$$ ) & continuous & $\begin{array}{l}\text { balance of pay- } \\
\text { ments }(B o P, \text { cur- } \\
\text { rent } \$)\end{array}$ & $\begin{array}{l}\text { Comparative Consti- } \\
\text { tution Project World } \\
\text { Bank }\end{array}$ \\
\hline${\text { Veto } \text { Player }_{j, t}}$ & number and ideological distance among domestic veto players & discrete & & Keefer (2012) \\
\hline Voice $_{j, t}$ & voice and accountability by country $j$ at time $t$ & continuous & score & World Bank \\
\hline
\end{tabular}


Table 3: Regional breakdown of the data

\begin{tabular}{|c|c|c|c|c|}
\hline Country & Number of Nuts2 regions & Administrative Units & Code & Observations \\
\hline Austria & 9 & States (Bundesländer) & AT & \\
\hline Belgium & 11 & Provinces (Provinces) & $\mathrm{BE}$ & Including Brussels \\
\hline Bulgaria & 6 & Regions (Rajoni za planirane) & BG & \\
\hline Czech Republic & 8 & Oblasts (Oblasti) & $\mathrm{CZ}$ & \\
\hline Croatia & 2 & Regions & $\mathrm{HR}$ & \\
\hline Cyprus & 1 & & CY & \\
\hline Denmark & 5 & Regions (Regioner) & DK & \\
\hline Estonia & 1 & & $\mathrm{EE}$ & \\
\hline Finland & 5 & Large Areas (Suuralueet/Storomraden) & FI & \\
\hline France & 22 & Regions (Régions) & FR & $\begin{array}{l}\text { Excluding Overseas Depart- } \\
\text { ment }\end{array}$ \\
\hline Germany & 39 & $\begin{array}{l}\text { Government Regions (Regierungs- } \\
\text { bezirke) }\end{array}$ & $\mathrm{DE}$ & \\
\hline Greece & 13 & Regions (Perifereies) & EL & NUTS2 regions 2000 \\
\hline Hungary & 7 & $\begin{array}{l}\text { Statistical Regions } \quad \text { (Terevèzesi- } \\
\text { statisztikai règiòk) }\end{array}$ & $\mathrm{HU}$ & \\
\hline Ireland & 2 & Regions & IR & \\
\hline Italy & 21 & Regions (Regioni) & IT & $\begin{array}{l}\text { Trentino-Alto Adige/Südtirol } \\
\text { is split in two region }\end{array}$ \\
\hline Latvia & 1 & & LV & \\
\hline Lithuania & 1 & & LT & \\
\hline Luxembourg & 1 & & $\mathrm{LU}$ & \\
\hline Malta & 1 & & MT & \\
\hline Netherlands & 12 & Provinces (Provincies) & NL & \\
\hline Poland & 16 & Voivodeships (Wojewòdztwa) & PL & \\
\hline Portugal & 7 & Autonomous Regions & PT & Including Acores and Madeira \\
\hline Romania & 8 & Regions (Regiuni) & RO & \\
\hline Slovakia & 4 & Oblasts (Oblasti) & SK & \\
\hline Slovenia & 2 & Macroregions (Kohezijshe regije) & SI & \\
\hline Spain & 19 & $\begin{array}{l}\text { Autonomous Communities and Cities } \\
\text { (Communidades y ciudades autòno- } \\
\text { mas) }\end{array}$ & ES & \\
\hline Sweden & 8 & National Areas (Riksomraden) & SE & \\
\hline United Kingdom & 40 & Counties & UK & \\
\hline
\end{tabular}

